Rok XV (2020) | 2 (30)| S. 107-119

https://doi.org/10.12797/LV.15.2020.30.09

Tomasz Kurdyła

Uniwersytet Jagielloński, Kraków

tomasz.kurdyla@uj.edu.pl

\title{
ZAGADNIENIE MOTYWACJI W GNIAZDOWYM OPISIE SŁOWOTWÓRSTWA GWAROWEGO (NA PRZYKŁADZIE GWARY ORAWSKIEJ)
}

Słowa klucze: słowotwórstwo, słowotwórstwo gwarowe, gniazda słowotwórcze, motywacja słowotwórcza

Keywords: word formation, dialectal word formation, word formation nests, motivation in word formation

Artykuł niniejszy poświęcono zagadnieniu motywacji słowotwórczej w ujęciu gniazdowym, zarówno w odniesieniu do gniazd słowotwórczych ogólnopolskich (gdyż dysponujemy jedynie takim opisem gniazdowym), jak i gwarowych, których opisem dialektologia polska jeszcze się nie zajęła. Jego celem jest sformułowanie metodologicznych propozycji postępowania w zakresie ustalania relacji motywacyjnych w gniazdach gwarowych ${ }^{1}$. Autor planuje zbadanie orawskich gniazd słowotwórczych na podstawie Słownika gwary orawskiej Józefa Kąsia (KąśSGO), dlatego prezentowany tu materiał gwarowy zaczerpnięto $\mathrm{z}$ tego słownika. Przedstawione poniżej propozycje należy traktować jako wstępne, wynikające po części z analizy niewielkiego jeszcze fragmentu KąśSGO.

Każdy badacz słowotwórstwa zgodzi się zapewne ze stwierdzeniem, że centralnym pojęciem tej dziedziny języka i językoznawstwa jest wykrywana przez parafrazę

1 W innym $\mathrm{z}$ kolei artykule pisałem o potrzebie i celach takich badań oraz o ich ograniczeniach (Kurdyła 2018). 
motywacja; Hanna Jadacka nazywa ją „najważniejszą kwestią teoretyczną słowotwórstwa opisowego" (2001: 26). To właśnie bowiem od przyjęcia takich, a nie innych zasad ustalania relacji derywacyjnych zależą: wyodrębnianie formantów słowotwórczych, ustalanie ich wartości kategorialnej i przypisanie derywatów do danych typów słowotwórczych oraz kategorii słowotwórczych. W konsekwencji zaś, zwłaszcza w opisach syntetycznych, monograficznych, przyjęcie danych rozstrzygnięć dotyczących ustalania motywacji ma znaczący wpływ na ostateczny kształt modelu systemu derywacyjnego danego języka bądź danej odmiany języka.

Trudności związane z ustalaniem kierunku pochodności i liczbą możliwych relacji derywacyjnych (motywacyjnych) oraz ich rodzajów pojawiły się na gruncie słowotwórstwa opisowego, nazywanego przez Profesora Mirosława Skarżyńskiego binarnym. Już przy pierwszych próbach definiowania derywatów synchronicznych i pochodności synchronicznej pojawiło się pytanie o to, czym jest motywacja synchroniczna oraz jak ustalać jej kierunek (tym samym kierunek pochodności). W dwóch najważniejszych syntezach polskiego słowotwórstwa opisowego definicje wyrazu motywowanego są podobne. W „żółtej gramatyce” jest to wyraz:

który znaczeniowo (lub składniowo) oraz formalnie wywodzi się od innego wyrazu, tzn. ściślej: wyraz, w którego znaczeniu i formie (temacie fleksyjnym lub jego części) zawarte jest znaczenie, a także forma innego wyrazu, zwanego podstawą słowotwórczą (bazą) (Grzegorczykowa, Puzynina 1998: 361).

Z kolei w podręczniku Alicji Nagórko jest to:

wyraz bardziej złożony pod względem formy i znaczenia, tj. zawierający w sobie znaczenie i formę innego leksemu stanowiącego jego bazę (podstawę słowotwórczą) (Nagórko 1998: 165).

Tak zdefiniowane relacje między leksemami dawały się łatwo uchwycić w regularnych, prostych interpretacyjnie derywatach modyfikacyjnych (dom $\rightarrow$ dom-ek 'dom' + 'mały'), mutacyjnych (mleko $\rightarrow$ mlecz-arnia 'mleko' + 'miejsce') czy transpozycyjnych (pisać $\rightarrow$ pis-anie), które, w porównaniu z ich podstawami słowotwórczymi, bez wątpienia cechuje większa złożoność semantyczna i formalna lub złożoność formalna i wtórność syntaktyczna w przypadku transpozycji. Jednak takie same rozstrzygnięcia w zastosowaniu do wielu innych leksemów motywowanych okazały się niewystarczające. Istnieją bowiem pary wyrazowe, w których wyższemu stopniowi komplikacji jednego z elementów towarzyszy mniejsza komplikacja innego lub które cechuje symetria semantyczna bądź formalna. Są to pary, w których zachodzi rozbieżność między złożonością semantyczną i formalną, ponadto takie, między którymi trudno ustalić większą/mniejszą złożoność; istnieją wreszcie derywaty, dla których można wskazać więcej niż jedną podstawę słowotwórczą. Możliwe są zatem zjawiska: 
1. Niedającego się ściśle ustalić kierunku motywacji, gdy zachodzi tzw. motywacja wzajemna, jak w parze stolarz: stolarstwo, w której możliwe są dwie parafrazy: stolarz $(\leftarrow$ stolarstwo $)$ 'ten, kto zajmuje się stolarstwem' i druga, zgodna z kierunkiem formalnym, stolarstwo $(\leftarrow$ stolarz) 'zajęcie stolarza'. Za derywaty uznaje się nazwy zawodów, zgodnie z kierunkiem złożoności formalnej (stolarstwo jako bardziej złożone formalnie: stol-ar-stwo). W typowych przypadkach motywacji wzajemnej nie tylko obie parafrazy są równoprawne, ale też stopień ich złożoności jest taki sam, np. optymizm 'bycie optymistąa : optymista 'ktoś, kogo cechuje optymizm'. Dla takich opozycji w słowotwórstwie przyjmuje się na ogół rozstrzygnięcia arbitralne i za derywaty uznaje się nazwy typu optymista (odatrybutywne nazwy nosicieli cech).

2. Wielomotywacyjności, gdy jeden derywat może mieć dwie równoprawne podstawy $^{2}$ - w praktyce - dwie równoprawne parafrazy słowotwórcze, np. brodacz 'człowiek brodaty' i 'człowiek z brodą', aptekarka 'kobieta aptekarz' i 'kobieta pracująca w aptece', słomianka 'wycieraczka słomiana' i 'wycieraczka ze słomy'. Autorki słowotwórstwa w „żółtej gramatyce” za podstawową w takich przypadkach uznają motywację formalną, bazowe są więc wyrazy najbliższe formalnie - a zatem brod-acz od brody, ponieważ motywacja przez brodatego wymaga objaśnień bardziej formalnie skomplikowanych, aptekar-ka (nie zaś ${ }^{\star} a p t e k$-arka) od aptekarz, słomian-ka od słomiany (Grzegorczykowa, Puzynina 1998: 386). W SGS o wyborze motywacji decyduje zarówno czynnik formalny (podstawa implikująca najprostszą technikę derywacyjną), jak i systemowość typu słowotwórczego, jego regularność (zob. Jadacka 2001: 26).

2.1. Motywacji podstawowej i towarzyszącej - dla derywatów typu słomianka motywacją podstawową jest wyraz bliższy formalnie słomian-ka (jest to więc motywacja bezpośrednia), jednak kryterium bliskości formalnej ma zastosowanie tylko tam, gdzie obie definicje są równoprawne. Dlatego dla derywatów typu stoczni-owiec w słowotwórstwie ogólnopolskim za motywujący wybiera się wyraz bliższy semantycznie (motywacja semantyczna), lepsza jest bowiem parafraza 'pracownik stoczni' niż 'pracownik stoczniowy' - za podstawową uznaje się zatem motywację pośrednią.

2.2. Motywacji równorzędnej - jedynie wówczas, gdy „różne parafrazy są równie dobre" (Grzegorczykowa, Puzynina 1998: 387), a żadna z wykrytych przez nie potencjalnych podstaw słowotwórczych nie jest w wyraźny sposób prostsza od derywatu, np. kreślarnia to zarówno 'pracownia kreślarska', jak i 'pracownia kreślarzy’3. Trudno jednak powiedzieć, czym miałyby się takie pary różnić od par optymizm -

2 Niekiedy trzy, np. drukarnia: drukować, drukarz, drukarski.

3 Możliwa jest też parafraza 'miejsce, w którym się kreśli': wówczas derywat tworzony jest lokatywnym formantem -arnia (jednak z wyżej określonych względów parafraza ta jest gorsza od dwóch pozostałych). 
optymista, zwłaszcza że w kreślarni można wskazać prostszą motywację formalną, otóż kreślar-nia pochodzi od kreślarz-a i jest to prosta sufiksacja, taką też motywację ma to locativum w SGS III pod redakcją Mirosława Skarżyńskiego; przyjęcie za podstawę przymiotnika prowadziłoby do uznania w tej formacji derywacji wymiennej, która jest mniej typowym sposobem tworzenia słów.

3. Motywacji zakłóconej stylistycznie - gdy wyraz motywujący bezpośrednio (formalnie) jest nacechowany stylistycznie, derywat zaś nie, a jego parafraza wskazuje na motywację pośrednią (semantyczną), nienacechowaną, np. nauczycielka (nienacechowana) 'kobieta, która uczy' $\leftarrow$ nauczać (podstawa bezpośrednia, nacechowana): uczyć (podstawa pośrednia, nienacechowana) ${ }^{4}$. W przypadkach takiej podwójnej motywacji (formalnie przez nauczać, semantycznie przez uczyć) za podstawową w słowotwórstwie ogólnopolskim uznaje się motywację pośrednią, 'ta, która uczy', podobnie tajemnica od taić, nie od tajemny, a księgarnia od książka, nie od księga.

Uznając zatem, przynajmniej w teorii, istnienie swego rodzaju „tła motywacyjnego" (złożoności relacji motywacyjnych, niedających się zamknąć w opozycjach binarnych) w opisach słowotwórczych - a więc i w modelach słowotwórstwa - eliminuje się je, dopuszczając tylko jedną motywację, dzięki czemu jednak możliwa jest jednoznaczna klasyfikacja derywatów.

Można by przypuszczać, że omówione problemy motywacyjne w sposób naturalny powinno rozwiązać słowotwórstwo gniazdowe. Takie deklaracje składają też badacze słowotwórstwa, np. M. Skarżyński (1999: 159) pisze: „gniazdo słowotwórcze jako model przedstawiający grupy wyrazów powiązanych relacjami motywacyjnymi wydaje się szczególnie dogodnym sposobem przedstawienia większości poznanych dotąd typów owych relacji”. Dalej jednak stwierdza, że ten typ badań słowotwórczych może mieć dwie postacie:

Po pierwsze, i ten sposób jest realizowany w polskich opisach gniazdowych [...], mogą one być modelami pokazującymi etapy [wyróżnienia - T.K.] generowania (derywowania) struktur słowotwórczych, a więc gniazdo widziane jest [...] jako zbiór [...] łańcuchów słowotwórczych o wspólnym początku. [...] Po drugie, można je konstruować tak, by modelowały one całość owych kilkupoziomowych relacji motywacyjnych (relacje semantyczne), co jednakże jest na tyle trudne, że ten typ interpretacji nie jest w opisach realizowany (ibid.: 161).

Hanna Jadacka, redaktor tomu rzeczownikowego SGS, we wstępie do słownika precyzuje tę kwestię, za nadrzędną uznając zasadę ,jednogniazdowości” derywatu jeden derywat nie może występować w różnych gniazdach i dwa derywaty nie mogą zajmować tego samego miejsca w jednym gnieździe (Jadacka 2001: 26). Z tego względu badacz musi zgodzić się na pewną arbitralność, pozostającą jednak najbliżej sy-

4 Możliwa jest jeszcze inna parafraza - 'kobieta nauczyciel'. 
stemowości modelu. Idzie o to, aby „uwydatnić zależności typowe, o największym stopniu regularności, najliczniejsze, a sam mechanizm derywacyjny przedstawić jak najprościej. [...] Chodzi bowiem o nadanie wykrytym zależnościom statusu relacji systemowych" (ibid.). Stąd też wspomniany wcześniej nacisk na systemowość, regularność typu słowotwórczego przy wyborze stosunków derywacyjnych.

Zdaniem badaczki sama natura gniazda usuwa problem pewnych typów wielomotywacyjności, ściślej motywację bezpośrednią i pośrednią (w derywatach typu słomianka), które w gnieździe są „wyraźnie widoczne poprzez strukturę »ogniw« poszczególnych łańcuchów" (ibid.: 27), por.:

\section{SŁOMA}

stomi-any

$$
\text { słomi|an-ka }
$$

- co jest zgodne z prawdą w sensie ogólnym (tj. wszystkie derywaty w gnieździe pokazane są w sieci relacji motywacyjnych pośrednich i bezpośrednich), jednak w sytuacjach problemowych owe możliwości motywacyjne są nie tyle usuwane, ile maskowane przez naturę gniazda, w takich bowiem wypadkach motywacja pośrednia (albo alternatywna) nie jest w gniazdach unaoczniana. Sam układ schodkowy, charakterystyczny dla wszystkich gniazd, niczego nie rozstrzyga. Rzecz w tym, że chcąc sprawdzić, czy w danym gnieździe występuje derywacja pośrednia, użytkownik słownika gniazdowego zmuszony jest do sprawdzania każdego łańcucha dwutaktowego i zastanawiania się, czy dany wyraz może być parafrazowany na dwa sposoby.

Rozstrzygnięcia kwestii szczegółowych dla SGS zaczerpnięto ze słowotwórstwa klasycznego (ibid.). Za bezpośrednią uznaje się motywację formalnie prostszą (słomianka od słomiany), ale tylko wówczas, gdy pozwala na to parafraza ('wycieraczka słomiana') - zob. fragment gniazda powyżej. Jeśli jednak parafraza nie jest

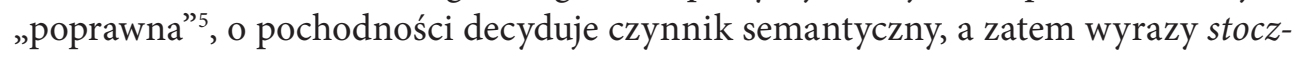
nia, stoczniowy, stoczniowiec będą już tworzyć inny układ gniazda:

\section{STOCZNIA}

stoczni-owy 'jak w stoczni, mający związek ze stocznią' stoczni-owiec 'pracownik stoczni'

- ponieważ z dwóch parafraz: 'pracownik stoczni' - 'pracownik stoczniowy' niepoprawna jest druga parafraza (mimo narzucającej się w gnieździe zależności od przymiotnika).

5 Hanna Jadacka nie rozwija kwestii „poprawności”, można jednak przypuszczać, że nie idzie tu o poprawność językową samej parafrazy, ale raczej o poprawność semantyczną (zob. dalsze przykłady). 
Ostatecznie kryteriami wyboru motywacji w przypadku wielomotywacyjności i motywacji wzajemnej są: dominacja systemowa, w przypadku zaś równouprawnionych definicji alternatywnych - kryterium formalne (ibid.: 28). Trudniejsze derywaty, których motywacja (a więc i pozycja w gnieździe) nie zawsze wynika z przyjętych założeń, opatrywane są przypisami.

Możliwości gniazd w zakresie wyrazistego przedstawiania tła derywacyjnego są zatem, co prawda w stopniu mniejszym niż w słowotwórstwie klasycznym, ograniczone. Można się chyba jednak zgodzić z redaktorami SGS, że na gruncie przyjętych metod (i założeń teoretycznych) są to najlepsze możliwe rozwiązania, zgodne z wymogami opisu naukowego, prowadzące do osiągnięcia zamierzonych celów badawczych $^{6}$. Dlatego badacz słowotwórstwa gwarowego, który chciałby je przedstawić, opisać i zanalizować w postaci gniazd, czego do tej pory w dialektologii polskiej nie robiono, nie staje przed koniecznością tworzenia od podstaw metody badawczej (w zakresie ustalania kierunku i liczby motywacji), może korzystać z gotowych wzorców. Rzecz jasna wzorce te wymagają dostosowania do swoistego materiału leksykalnego, jakim jest słownictwo gwarowe.

Słowom gwarowym przypisuje się konkretne lokalizacje. Taki ich charakter znajduje odbicie w postaci pewnych dysproporcji widocznych w słownikach gwarowych, także w KąśSGO. Są to dysproporcje o charakterze ilościowo-jakościowym, a więc różnice w poświadczeniach danych derywatów i centrum gniazda na całym obszarze gwarowym, np. derywat bednarka i jego warianty (bednárka i bedniárka) 'klepka w bedni' mają w KąśSGO (I: 25) 18 poświadczeń, natomiast centrum gniazda BEDNIA 'skrzynia lub naczynie $z$ desek' - jedynie $6^{7}$. Rodzi się wobec tego pytanie: czy w odniesieniu do wsi, w których nie odnotowano podstawy słowotwórczej, można mówić o motywacji słowotwórczej i w ogóle o derywacji? Kolejny przykład w gnieździe:

BAZIA - występuje w 1 wsi, bazi-icka - występuje w 2 wsiach

6 A ponadto, stwierdza H. Jadacka (2001: 28), przyjęte rozstrzygnięcia w zakresie motywacji „bliskie są intuicyjnemu widzeniu zjawisk językowych”, „tak na ogół widzą je nie językoznawcy”. Do kwestii intuicji słowotwórczej użytkowników wracam w zakończeniu artykułu.

7 Dysproporcje te nie muszą oddawać rzeczywistego stanu w gwarach, mogą być - i często są efektem niekompletności materiału wyekscerpowanego przez leksykografa na potrzeby słownika, braku tak samo obszernego i reprezentatywnego materiału z wszystkich badanych wsi. 
Czy zatem w ogóle wyrazy typu bednarka, bazicka można traktować w wielu wsiach jako motywowane słowotwórczo ${ }^{8}$ Gdyby badania dotyczyły konkretnej wsi, w której nie odnotowano podstaw słowotwórczych - zapewne nie, kiedy jednak bada się zespół gwarowy, potraktowanie ich słowotwórczo jest uprawnione, a nieobecność poświadczeń w niektórych wsiach należących do danego zespołu traktuje się jako swego rodzaju lukę - efekt wspomnianych wyżej niedostatków materiałowych. Mogą to być co prawda genetycznie zapożyczenia wewnątrzgwarowe, tj. kilka(naście) wsi przejmuje derywat - lecz bez podstawy - znany pierwotnie tylko we wsiach, w których używana jest także podstawa, z perspektywy synchronicznej jednak będą to $\mathrm{w}$ danym zespole gwarowym wyrazy połączone związkami motywacji. Dodam jeszcze na marginesie, że KąśSGO notuje stosunkowo dużą liczbę leksemów niewątpliwie derywowanych w tym sensie, że da się w nich wydzielić przyrostek słowotwórczy, równocześnie jednak w tymże słowniku brak ich podstaw. W takiej sytuacji z definicji nie można mówić o pochodności słowotwórczej, dlatego za wyrazy niemotywowane trzeba uznać np. takie leksemy, jak: asyntyrkalasyntyrunek (KąśSGO I: 11), azotniak (ibid.: 13), bagaźnik (ibid.: 17), bajtlák (ibid.: 18), bakaniec (ibid.: 18), bandzista (w KąśSGO brak hasła banda w znaczeniu 'kapela') (ibid.: 19), bateryjka (ibid.: 22), bdzina (ibid.: 24), bocniarka 2 (ibid.: 42); w słowniku są: plotkarz, plotkara, plotkować (KąśSGO II: 50), lecz nie ma plotki. A może właściwy jest odwrotny kierunek motywacji, tj. bednia 'naczynie z bednarek' jest derywatem od powszechniejszej bednarki, a centrum gniazda jest jeszcze inne (w takim parafrazowaniu bednia byłaby derywatem z formantem ujemnym od bednarki)? Teoretycznie jest to możliwe, ale pochodność bedni (lub motywację wzajemną tych formacji) można odrzucić. Kierując się bowiem nie tylko rozsądkiem, ale nade wszystko określonymi wyżej kryteriami ustalania kierunku motywacji, za derywat uznamy bednarkę, gdyż: a) stopień złożoności semantycznej bednarki 'to, z czego robi się bednie' jest większy niż bedni, b) struktura morfologiczna jest bardziej złożona (-ar-ka) niż w wypadku bedni. Oba te czynniki wyraźnie wskazują na kierunek derywacji. Ponadto odwrotny kierunek motywacji (bednia od bednarki) byłby zjawiskiem wyjątkowym, niezgodnym z kryterium dominacji systemowej - inne bowiem leksemy na -arka (lub -árka) są (w zbadanym dotychczas materiale) derywatami od podstaw prostszych, zazwyczaj bezsufiksalnych, por.:

BAL 'bela, np. słomy, siana'

bal-árka 'maszyna do robienia bali' [derywacja sufiksalna odrzecz.] ...

8 Podobne pytania, nierzadko w szerszej, dialektalnej perspektywie, stawia w swych artykułach Jerzy Sierociuk (zob. m.in. 1996, 1998, 2007a). 
BARÁN I 1 'samiec owcy'

baran-ek 3 'serek o kształcie barana'

barani-arka 'forma do robienia baranków' [derywacja wymienna odrzecz.]

BOK 2 'strona lub krawędź czegos'

boc-ni 'przym. (znajdujący się z boku czegoś)'

bocni-arka 1 // bocn-ica 'bocnia deska (w descáku lub gnojáku)’ [derywacja sufiksalna odprzym.] ...

W podanych przykładach $\mathrm{w}$ formach $\mathrm{z}$-arka występuje derywacja sufiksalna (względnie wymienna), brak jednak przykładów na derywację ujemną od leksemów $\mathrm{z}$-arka. Nie odnotowałem jeszcze zależności zupełnie proporcjonalnych, tj. takich, w których formant -arka miałby tę samą wartość kategorialną co w bednarce (nazwa materiałowa), nie można jednak wykluczyć, że takowe się pojawią.

Dla niektórych leksemów warto zatem podawać informacje o lokalizacjach, ale też nie powinny one mieć w ustalaniu stosunków motywacyjnych pierwszeństwa.

Rzecz komplikuje się w głębszej (niższej) części gniazda, gdzie występuje kolejny derywat, bednarz. W KąśSGO definiowany jest on jako 'rzemieślnik wytwarzający beczki i inne naczynia z bednárek' (I: 25), definicja sugeruje zatem, że jest to derywat od bednárki. Nie można jednak wykluczyć motywacji przez bednię, która jednocześnie daje prostszą parafrazę 'rzemieślnik robiący bednie', a nie 'rzemieślnik robiący naczynia z bednarek' (właśnie takie wybiera się przy parafrazach konkurencyjnych). Gdyby nawet uznać parafrazy za alternatywne, równoprawne - wówczas decyduje czynnik formalny - motywacją bezpośrednią bednarza byłaby bednia, a za taką (a jednocześnie bardziej systemową) trzeba by uznać afiksację (jak przy bednia $\leftarrow$ bedn-arz), a nie ucięcie (jak przy bedn-arka $\leftarrow$ bedn-arz<-ka>):

\begin{tabular}{|c|c|}
\hline $\begin{array}{l}3 \text { BEDNIA } \\
\text { bedn-arka } \\
\text { bedn-arz }\end{array}$ & a nie \\
\hline
\end{tabular}

Możliwy jest jednak jeszcze inny układ gniazda, zgodnie z którym bednarka nie została utworzona (jak stwierdziliśmy na wstępie) od bedni, lecz od bednarza, jako 'to, co robi bednarz' (nazwa wytworu):

4 BEDNIA

bedn-arz

bedn-ar-ka 
A zatem za centrum gniazda należy uznać słabiej poświadczoną, za to najprostszą formalnie i semantycznie BEDNIĘ. Bednarz jest derywatem tworzonym w pierwszym takcie od bedni, natomiast bednarka ma dwie możliwe interpretacje: jest derywatem w pierwszym takcie (bezpośrednio od BEDNI - przykład 3) lub w drugim (od bednarza - przykład 4). Za drugą interpretacją przemawia kryterium formalne, powiązanie bednarki $\mathrm{w}$ gnieździe $\mathrm{z}$ bednarzem pozwala wydzielić $\mathrm{w}$ niej prostszy sufiks - $k a$ (zgodnie z zasadą, że „jeśli analiza semantyczna nie rozstrzyga [...], za bezpośrednią uznajemy motywację formalnie prostszą", Jadacka 2001: 27). Kompletne gniazdo BEDNIA wyglądałoby zatem tak:

5 BEDNIA 1 'wielkie naczynie drewniane' pok. III (zob. DEBNA/DEBNIA) bedn-árz 'rzemieślnik wytwarzający bednie'

bedn-ar-ka / bedn-ár-ka I / bedni-ár-ka rzad. 'to, co robi bednarz' (zob. WÓNTORA)

bedn-arz-two / bedn-ár-ka II 'zajęcie bednárza'

bedn-arz-ić 'być bednárzem'

Niekiedy mogą pojawić się wątpliwości, czy można dane wyrazy, podobne do siebie formalnie i znaczeniowo, uznać za powiązane motywacją słowotwórczą. Czy np. do gniazda rzeczownika ANGLIJA można włączyć rzeczownik angiełka 'choroba angielska (krzywica)' (KąśSGO I: 6)? Zarówno jego definicja słownikowa, jak i nasuwająca się parafraza słowotwórcza wskazują na podstawę przymiotnikową, jednak w KąśSGO nie ma przymiotnika ${ }^{*}$ angielski. Występuje natomiast przymiotnik anglicki, motywowany przez rzeczownik ANGLICKO 'ts. co Anglija' (ibid.: 7) - zarówno bazowy rzeczownik, jak i przymiotnik mają jedynie trzy wspólne lokalizacje, Anglija natomiast ma lokalizację ogólnoorawską. Zarówno to, jak i względy formalne przemawiają za tym, aby stworzyć dwa oddzielne gniazda - z bazą ANGLICKO:

\section{ANGLICKO 'Anglia' (zob. ANGLIJA I) 3 wsie anglicki 2 'przym.'}

oraz z bazą ANGLIJA. W jaki sposób jednak połączyć z nią rzeczownik angiełka (skoro nie pozwala na to parafraza)? Przez dopisanie innego ogniwa, przymiotnika angielski, który jak wspomniałem, jako leksem nie występuje w słownictwie Orawian, funkcjonują w nim jednak zestawienia współtworzone przez ten przymiotnik: angielská choroba/chorość, angielskie ziele (ibid.: 6). Sądzę, że takie postępowanie jest badawczo uzasadnione. Gdyby nie to, angiełkę należałoby uznać za wyraz niemotywowany, z opisu zaś zniknęłoby jedno gniazdo?:

9 Natomiast w słowotwórstwie binarnym trzeba by ten derywat uznać za uniwerbizację zestawienia choroba angielska - co także przemawia za powiązaniem angiełki z przymiotnikiem angielski. 
7 ANGLIJA I 'Anglia' (zob. ANGLICKO) ogor. pol.

angiel-ski (fraz)

angiet- $k a$ 'choroba angielska' pok. III, 1 wieś

Jednakże takie działania nie mogą być podejmowane automatycznie, tj. gdy budowa słowotwórcza jakiegoś wyrazu sugeruje taki, a nie inny wyraz motywujący, którego jednak w KąśSGO nie ma (nawet w postaci zestawienia lub frazeologizmu), należy respektować ograniczenia bazy materiałowej i łączyć dany derywat (jeśli pozwala na to parafraza) z innymi elementami gniazda. Wyjaśnijmy to na przykładzie niewielkiego fragmentu rozbudowanego gniazda BABA. Wśród derywatów znajduje się babecka (ibid.: 14), formacja o odmiennej motywacji semantycznej i formalnej. Jego forma kazałaby łączyć go w bezpośrednim takcie $\mathrm{z} b a b k a$, tę zaś bezpośrednio z babą; wspólnie tworzyłyby one łańcuch:

$8 \mathrm{BABA}$

$b a b-k a$

$b a b-e c-k a$ [formant deminutywny złożony -ec-ka]

Parafraza ujawnia jednak inną podstawę 'pejoratywnie o babie’ - ponieważ tylko ten wyraz ma w KąśSGO znaczenie 'kobieta', babka zaś w takim znaczeniu nie występuje $^{10}$, co wymaga innego ułożenia taktów:

\section{$9 \mathrm{BABA}$}

$b a b-k a$

bab-ecka [formant deminutywny prosty]

Spójrzmy na jeszcze jeden, ostatni już przykład, który przy przestrzeganiu omówionych założeń powinien dać gniazdo:

10 BÁJKA 1 'plotka'

bájc-árz// bájk-árz // baj<k>árz 'pejor. mężczyzna rozpowiadający bájki' bájcár-ka 'pejor. kobieta bájcárz'

bájc-yć 'opowiadać bajki'

bájc-aty 'przym.'

Podkreślona motywacja (takt bájcárz $\leftarrow$ bájcár-ka) jest niezgodna $\mathrm{z}$ ustaleniami niektórych dialektologów, wyróżniających wśród gwarowych kategorii słowotwórczych nazwy żeńskich subiektów; bájc-árkę łączyliby oni motywacyjnie z czasowni-

10 Ma ona w gwarze orawskiej trzy znaczenia: 1. 'żona dziadka', 2. 'rodzaj kowadełka', 3. 'roślina'. 
kiem bájcyć, na nią bowiem wskazywałyby parafrazy użytkowników języka 'ta, która bajcy'. W badaniach derywacji gwarowej nierzadko wyzyskuje się intuicję językową użytkownika i jego parafrazy słowotwórcze, uwzględnia się je w opisie (Sierociuk 1996, 2007b; Gala 2000; Kurdyła 2011), taką możliwość dają bowiem badania terenowe słowotwórstwa. Jednak badania słownikowe ją wykluczają, badacz ograniczony jest do informacji semantycznych zawartych w definicjach haseł słownikowych (uzupełnionych ewentualnie przez przykładowe konteksty użyć leksemów) - zarówno w badaniach słowotwórstwa gwarowego, jak i ogólnopolskiego. Czy wobec tego nie nazbyt „optymistycznie” brzmią słowa ze wstępu SGS (przywołane już w przypisie 6) o tym, że przyjęte w nim rozstrzygnięcia w zakresie motywacji „bliskie są intuicyjnemu widzeniu zjawisk językowych” i że "tak na ogół widzą je nie językoznawcy" (Jadacka 2001: 28)? Intuicja użytkownika przewija się w dyskusji metodologicznej (lub na jej marginesie) przez cały okres rozwoju polskiego słowotwórstwa opisowego, w rzeczywistości jednak w analizie słowotwórczej i w opisie słowotwórczym nie jest wykorzystywana. Pozostaje ona jednak dość wyraźna w teorii słowotwórstwa, ściślej: w definiowaniu synchronicznej pochodności słowotwórczej, rozumianej jako współcześnie dostrzegane, uświadamiane przez użytkowników języka relacje semantyczne i formalne między dwoma wyrazami. De facto zatem postulowano opis słowotwórczy „rozumiany [...] jako opis intuicji językowej współczesnego użytkownika języka" (Skarżyński 1999: 38). Rzecz w tym, że nikt (poza pewnymi wyjątkami) nie prowadził badań słowotwórstwa ogólnopolskiego w oparciu o wywiady lub kwestionariusze. Dlatego też, stwierdza M. Skarżyński:

niedostatek empirycznej wiedzy o kompetencji użytkowników języka w zakresie dostrzegania przez nich relacji międzywyrazowych zmusza do formułowania w mniejszym lub większym stopniu arbitralnych dyrektyw metodologicznych. Arbitralność zaś zawsze jest w pewnym stopniu naznaczona subiektywizmem (ibid.).

W innym miejscu Profesor wyraża tę myśl w bardzo dla siebie charakterystyczny sposób: otóż możliwość testowania intuicji użytkowników „sprowadza się do możliwości sprawdzania "Krewnych i Znajomych Królika«" (ibid.: 60).

Modele słowotwórstwa tworzone w oparciu o materiał słownikowy, pomijające badania intencji użytkowników, z natury rzeczy zatem będą obarczone subiektywnością, uproszczeniem i idealizacją. Jednakże owej intencji mówiących nie wolno też przeceniać, czego dowiodły eksperymenty słowotwórcze Alicji Nagórko-Kufel (1977), mające na celu rozpoznanie świadomości słowotwórczej użytkowników polszczyzny literackiej. Wynika z nich m.in., że na ogół przypisują oni derywatom więcej niż jedną tylko podstawę: „wyraz motywujący uwikłany jest w sieć relacji motywacyjnych w obrębie gniazda słowotwórczego" (ibid.: 146), kierują się najczęściej bliskością formalną, nie zaś semantyczną (np. drapieżca od drapać, głośnik od głośny). W przypadku „prostych”, czytelnych słowotwórczo derywatów ich motywacje zgadzają się na ogół z tymi, które przyjmują językoznawcy (np. dla rzeczownika 
kamienica $70 \%$ respondentów podało motywację rzeczownikową (z) kamienia, 23\% przymiotnikową kamienny - także w SGS kamienica związana jest motywacyjnie w pierwszym takcie z kamieniem). Można zatem uznać, że gniazdowy model słowotwórczy - w którym co prawda motywację formalną i semantyczną traktuje się na równi, ale w przypadkach alternatywnych rozstrzyga kryterium formalne i systemowość (regularność) relacji - przynajmniej częściowo zgodny jest $\mathrm{z}$ intuicją użytkowników. Tej jednak w przygotowywanym opracowaniu gniazdowego słowotwórstwa Orawy wykorzystywać nie będę, uznając systemowość za nadrzędny czynnik decydujący o umiejscowieniu derywatu w konkretnym miejscu w gnieździe.

\section{Literatura}

Gala S., 2000, O pewnych wyznacznikach słowotwórstwa gwarowego, „Prace Filologiczne” XLV, s. $173-178$.

Grzegorczy kowa R., Puzynina J., 1998, Problemy ogólne słowotwórstwa, [w:] R. Grzegorczykowa, R. Laskowski, H. Wróbel (red.), Gramatyka współczesnego języka polskiego, t. II: Morfologia, wyd. 2. zm., Warszawa, s. 361-388.

JADACKA H., 2001, Wstęp, [w:] T. Vogelgesang, Słownik gniazd słowotwórczych współczesnego języka ogólnopolskiego, t. 1: Gniazda odprzymiotnikowe, red. H. Jadacka, Kraków, s. 7-32.

KąśSGO: J. Kąś, Słownik gwary orawskiej, t. I-II, wyd. 2. popr., Kraków 2011.

KuRdyŁA T., 2011, Funkcje formantów rzeczownikowych w polszczyźnie ludowej (na przykładzie trzech wsi podkarpackich), „Biblioteka LingVariów”, t. 12, Kraków.

KuRdyŁA T., 2018, Założenia ogólne badań gwarowych gniazd słowotwórczych. Źródła leksykograficzne (gwary małopolskie), [w:] M. Bańko, H. Karaś (red.), Między teorią a praktyką. Metody wspótczesnej leksykografii, „Biblioteka Prac Filologicznych”, t. 1, s. 129-143.

NAGór ко A., 1998, Zarys gramatyki polskiej (ze słowotwórstwem), wyd. 3 rozsz., Warszawa.

NAGóR KO-Kufel A., 1977, O eksperymencie w badaniach słowotwórczych, „Biuletyn Polskiego Towarzystwa Językoznawczego" XXXV, s. 141-151.

SGS: Słownik gniazd słowotwórczych współczesnego języka polskiego, t. I: Gniazda odprzymiotnikowe, T. Vogelgesang, Kraków 2001, t. II: Gniazda odrzeczownikowe, H. Jadacka (red.) oraz M. Bondkowska, I. Burkacka, E. Grabska-Moyle, T. Karpowicz, Kraków 2001, t. III: Gniazda odczasownikowe, M. Skarżyński (red.) oraz M. Berend, M. Bondkowska, I. Burkacka, H. Jadacka, M. Olejniczak, T. Vogelgesang, cz. 1-2, Kraków 2004, t. IV: Gniazda motywowane przez liczebniki, przysłówki, zaimki, przyimki, modulanty, onomatopeje, wykrzykniki, M. Skarżyński, Kraków 2004.

Sierociuk J., 1996, Wybrane problemy metodologii badań i opisu słowotwórstwa gwarowego, [w:] B. Dunaj, J. Reichan (red.), Studia dialektologiczne, t. 1, s. 197-205.

Sierociuk J., 1999, Język wsi jako odbicie uwarunkowań lokalnych, „Biuletyn Polskiego Towarzystwa Językoznawczego" LV, s. 131-139.

Sierociux J., 2007a, Problemy ustalania repertuaru kategorii słowotwórczych $w$ dialektach polskich, [w:] H. Burkhardt, A. Nagórko (red.), Sprachliche Kategorien und die slawische Wortbildung, „Slawistiche Forschungen und Texte. Literatur, Sprache, Kultur” 6, Hildesheim - Zürich - New York 2007, s. 447-459. 
Sierociuk J., 2007b, Swoistość słowotwórstwa gwarowego (wybrane problemy), „LingVaria” $\operatorname{nr} 1$ (3), s. 115-125.

SKARŻYŃski M., 1999, Powstanie i rozwój polskiego słowotwórstwa opisowego, Kraków.

\section{The Question of Motivation in Nest-Oriented Description of Dialectal Word Formation (Using the Example of the Orava Dialect) Summary}

The paper discusses word formation's most important notion, i.e. the motivation, in respect to nestoriented descriptions. The first part presents the difficulties which arise in the traditional, as well as in the nest-oriented description of word formation of general Polish (mutual motivation, multiple motivations, indirect and direct motivation, base and accompanying motivation, equivalent motivation). In the second part, these problems of motivation, resulting from the specificity of dialectal material, are being discussed. This part also formulates methodological suggestions about the creation of certain nests which are more difficult to analyse. The final part tackles the question of mutual dependence between the model of word formation, and the speaker's word formation intuition (awareness, competence). 